(c) American Dairy Science Association, 2005.

\title{
Relationship Between Physical Properties of Casein Micelles and Rheology of Skim Milk Concentrate
}

\author{
A. O. Karlsson, ${ }^{1}$ R. Ipsen, ${ }^{1}$ K. Schrader, ${ }^{2}$ and Y. Ardö ${ }^{1}$ \\ ${ }^{1}$ Dairy Technology, Department of Food Science, Centre for Advanced Food Studies, \\ The Royal Veterinary and Agricultural University, Rolighedsvej $30^{5}, 1958$ Fredriksberg C, Denmark \\ ${ }^{2}$ Federal Research Centre for Nutrition and Food, Location Kiel, Hermann-Weigmann-Str. 1, \\ 24103 Kiel, Germany
}

\begin{abstract}
The properties of casein micelles in milk concentrates are of interest for the use of ultrafiltered (UF) skim milk concentrates in dairy products, and for the general understanding of colloidal stability and behavior of the casein micelle. The rheological behavior of UF skim milk concentrate with a casein concentration of $19.5 \%$ (wt/wt) was investigated at different $\mathrm{pH}$ and $\mathrm{NaCl}$ concentrations by analyzing flow viscometry and small amplitude oscillatory shear measurements. Viscometric flow curves were fitted to the Carreau-Yasuda model with the aim of determining values for the viscosity at infinite high shear rates and thereby estimate the voluminosity of the casein micelles $\left(\nu_{\text {casein }}\right)$ in the UF concentrate. The voluminosity of the casein micelles increased with addition of $\mathrm{NaCl}$ and decreased when $\mathrm{pH}$ was decreased from 6.5 to 5.5 . At $\mathrm{pH} 5.2, \nu_{\text {casein }}$ increased because of acid-induced aggregation of the casein micelles. The changes in $\nu_{\text {casein }}$ could be interpreted from transmission electron microscopy of freezefractured samples of the UF concentrate and partly from dynamic light scattering measurements. Altered interactions between casein micelles due to different $\mathrm{pH}$ and $\mathrm{NaCl}$ concentrations are proposed to occur due to collapse of the $\kappa$-casein layer, changed ionic strength, and altered distance between casein micelles.
\end{abstract}

(Key words: Carreau-Yasuda model, concentrated skim milk, rheology, ultrafiltration)

Abbreviation key: $\nu_{\text {casein }}=$ voluminosity of casein micelle.

\section{INTRODUCTION}

Unconcentrated skim milk of native $\mathrm{pH}$ behaves as a Newtonian fluid; that is, the viscosity is independent of the shear rate (Bienvenue et al., 2003a). Parameters

Received April 25, 2005.

Accepted July 18, 2005.

Corresponding author: Anders Ola Karlsson; e-mail: aka@kvl.dk. influencing the viscosity are the concentration of total solids, temperature, and heat treatment. The casein micelles, which have a hydrodynamic diameter of 40 to $300 \mathrm{~nm}$, harbor the main part of casein in milk, and they are considered colloids in an aqueous solute (i.e., serum, containing mainly whey proteins, lactose, and minerals). The casein micelles are stabilized from aggregating by steric and electrostatic stabilization due to $\kappa$-casein molecules situated on the surface of the micelles. Because of their relatively high concentration and frequent interactions, the casein micelles contribute largely to the viscosity of skim milk (Walstra and Jenness, 1984). Changes in the physicochemical properties of the casein micelles can be induced by adjusting $\mathrm{pH}$ or adding salts. Dalgleish and Law (1988) showed that when decreasing $\mathrm{pH}$ to the range 6.1 to 5.5, the amount of casein bound to the casein micelles decreased. Addition of $\mathrm{NaCl}$ to milk has been shown to increase hydration of the casein micelles (Grufferty and Fox, 1985). When water is removed and the concentration of total solids in skim milk is increased as during ultrafiltration, the distance between the casein micelles decreases. This forces the micelles to interact more frequently with each other because of decreased distance (de Kruif, 1997). This leads to an increased apparent viscosity and the fluid starts to behave like a shearthinning non-Newtonian fluid. At high concentrations of casein, the rheological properties of skim milk concentrates are sensitive to changes in the voluminosity of casein micelles (Snoeren et al., 1982) and altered interactions between them.

Rheological properties of milk concentrates in viscometric Couette flow have previously been described by the power-law model (Solanki and Rizvi, 2001) and the Herschel-Bulkley model (Vélez-Ruiz and Barbosa-Cánovas, 1998). The Herschel-Bulkley model also includes a term that is proposed to give a measure for a yield stress. Both models describe the shear-thinning properties of milk concentrates and other shear-thinning dairy products (e.g., stirred yogurt and dairy desserts). However, with more sophisticated instrumentation, shearthinning fluids have been shown to not be shear thin- 
ning at very low or very high shear rates. Previously mentioned models are thus not suitable for predicting the flow properties over a wider shear rate interval. The Carreau model (Bird et al., 1987) can be seen as an extension of the power-law model because it not only describes the power-law behavior but also regimens of Newtonian flow at very low and very high shear rates. The 2 Newtonian regimes are often referred to as the Brownian and the hydrodynamic regimes, respectively. The Carreau model has been proven useful in describing the flow of dairy desserts (Tárrega et al., 2005). Yasuda modified the Carreau model and added one more parameter (Bird et al., 1987).

The Einstein relation has been used to relate the volume fraction $(\Phi)$ of dispersed hard spheres in a solute to the viscosity $(\eta)$ of the dispersion. This relation is however only valid for dilute systems, in which the particles are not affected by each other's presence (Barnes et al., 1989). For more concentrated dairy systems, the empirical Eilers equation (Eq. [1]) is more useful for estimating viscosity:

$$
\eta=\eta_{0} \cdot\left(1+\frac{1.25 \Phi}{1-\Phi / \Phi_{\max }}\right)
$$

where $\eta_{0}$ is the viscosity of the continuous phase and $\Phi_{\max }$ is the maximum packing volume fraction of the dispersed particles (Eilers, 1941). The total volume fraction $\Phi$ is:

$$
\begin{gathered}
\Phi=\Phi_{\text {casein }}+\Phi_{d w}+\Phi_{n w} \\
=C_{c a s e i n} \cdot \nu_{c a s e i n}+C_{d w} \cdot \nu_{d w}+C_{n w} \cdot \nu_{n w}
\end{gathered}
$$

where $C$ is the mass concentration and $\mathrm{v}$ is the protein voluminosity. The indices indicate fractions of casein, denaturated whey protein $(d w)$, and native whey protein $(n w)$. Snoeren et al. (1982) used Eq. [1] and Eq. [2] to calculate $\Phi_{\text {casein }}$ in evaporated milk and Hallström and Dejmek (1988) used Eq. [1] for calculating the voluminosity of protein in heat-treated UF skim milk. The Eilers relation was originally developed for hydrodynamic interacting particles (Eilers, 1941)

The objective of this work was to explore the rheological behavior of UF skim milk concentrate, which has a high protein concentration; therefore, the casein micelles are assumed to interact over very short distances. This type of UF concentrate is mainly used for the production of cast-cheese. The flow behavior was studied over a wider shear-rate interval than before, and the flow was predicted by the Carreau-Yasuda model. Efforts have been made to relate the changed rheological behavior of the UF concentrate due to addition of $\mathrm{NaCl}$ and acid to changes in the voluminosity of casein $\left(\nu_{\text {ca- }}\right.$ sein) and altered interactions between casein micelles. Compared with previous studies, the rheological results are supported by transmission electron microscopy of UF concentrate and size measurements of casein micelles by dynamic light scattering. The results are of importance to further extend the knowledge about the colloidal stability and the behavior of casein micelles and are of particular interest for the use of high-protein UF skim milk concentrates in dairy processing.

\section{MATERIALS AND METHODS}

\section{Preparation of Samples of UF Skim Milk}

Low-pasteurized $\left(73^{\circ} \mathrm{C}, 15 \mathrm{~s}\right)$ skim milk was bought from a local dairy and heated to $50^{\circ} \mathrm{C}$. The UF process was carried out using a DDS UF Lab-module 20-0.36 (APV, Silkeborg, Denmark) equipped with GR61PP membranes (APV) with a nominal molecular weight cut-off of 20,000 Da. The UF process was stopped when the retentate had a Brix value of $36.2^{\circ}$. If the UF concentration was continued when the concentrate had higher Brix values, gel cakes developed on the UF membranes and the efficiency of the process was greatly reduced. The Brix value was measured with a handheld refractometer (Atago Co., Tokyo, Japan). After the concentration process, the UF concentrate was poured into bottles $\left(100 \mathrm{~mL}\right.$ ) and pasteurized at $62^{\circ} \mathrm{C}$ for $30 \mathrm{~min}$. The pasteurized UF concentrate was then rapidly cooled to approximately $4^{\circ} \mathrm{C}$ in water bath before frozen storage $\left(-23^{\circ} \mathrm{C}\right)$. Compared with fresh UF concentrate, the rheological properties and casein micelle size of frozen stored UF concentrate was shown to be not significantly different (results not shown).

Before use in experiments, the UF concentrate was thawed in a water bath $\left(30^{\circ} \mathrm{C}\right)$ for $60 \mathrm{~min}$. Thimerosal (0.02\% wt/wt; Merck, Darmstadt, Germany) was added as preservative and the UF concentrate was stored for $24 \mathrm{~h}$ at $30^{\circ} \mathrm{C}$. The UF concentrate was then poured into plastic beakers and glucono- $\delta$-lactone (Acros Organics, Goel, Belgium) was added to obtain the desired final $\mathrm{pH}(6.1,5.8,5.5$, or 5.2 after $24 \mathrm{~h})$. Sodium chloride or $\mathrm{KCl}$ (Merck) was added to a final concentration of 0 , 0.33 , or $0.66 \mathrm{~mol} / \mathrm{kg}$ of UF concentrate. Because glucono$\delta$-lactone slowly acidifies UF concentrate (7 to $10 \mathrm{~h}$ ), the samples were placed at $30^{\circ} \mathrm{C}$ for $24 \mathrm{~h}$ to ensure that the samples reached final $\mathrm{pH}$ before any measurements on the samples were performed.

\section{Chemical Analyses}

The $\mathrm{pH}$ was directly measured using a Knick Portamess (Knick Elektronische Messgeräte, Berlin, Germany) equipped with a Hamilton Tiptrode (Hamilton Instruments, Bonaduz, Switzerland). Total solids were 
Table 1. Composition of skim milk and UF concentrate.

\begin{tabular}{lcc}
\hline & Skim milk & UF concentrate \\
\hline Total solids, \% (wt/wt) & $9.20 \pm 0.01$ & $30.48 \pm 0.07$ \\
$\mathrm{pH}\left(\right.$ at $\left.30^{\circ} \mathrm{C}\right)$ & 6.67 & 6.51 \\
Total $\mathrm{Ca}, \mathrm{mg} / 100 \mathrm{~g}$ & $1250 \pm 16$ & $6807 \pm 125$ \\
Total $\mathrm{P}, \mathrm{mg} / 100 \mathrm{~g}$ & $927 \pm 25$ & $4131 \pm 90$ \\
Lactose, \% (wt/wt) & $5.1 \pm 0.1$ & $4.1 \pm 0.1$ \\
Casein, \% (wt/wt) & 2.7 & 19.5 \\
Whey protein, \% (wt/wt) & 0.5 & 3.8 \\
\hline
\end{tabular}

determined according to the IDF standard method (International Dairy Federation, 1991a). Nitrogen was determined using with a Kjeltec System 1026 Analyzer (Tecator, Höganäs, Sweden). Total N, noncasein N, and NPN were determined according to IDF standard methods (International Dairy Federation, 1993). The protein content was estimated by multiplying the nitrogen content by a Kjeldahl factor of 6.36 for casein and 6.28 for whey protein (van Boekel and Ribadeau-Dumas, 1987). The determination of lactose was made with a lactose/Dgalactose enzymatic BioAnalysis kit (Scil Diagnostica, Martinsried, Germany) according to the instructions of the manufacturer, and the reference method (International Dairy Federation, 1991b). Total content of calcium was determined using atomic absorption spectroscopy (Perkin-Elmer, Boston, MA) according to the method described by Le Graët and Gaucheron (1999). Concentration of total phosphorus was spectrophotometrically determined using a Gensys instrument (Spectrinic Unicam, Rochester, MN). Preparation of the samples for analysis of phosphorus was according to the IDF standard method (International Dairy Federation, 1987). All chemical analyses were performed in duplicate at least. The chemical composition of skim milk and UF concentrate is summarized in Table 1.

\section{Dynamic Light Scattering}

The average particle size, expressed as the z-average hydrodynamic diameter, of casein micelles was measured by dynamic light scattering. The equipment used was a Malvern HPPS from Malvern Instruments (Malvern, UK). The instrument uses a laser with a wavelength of $633 \mathrm{~nm}$ and the intensity of scattered light is detected at the $173^{\circ}$ angle. A cumulant analysis of the intensity autocorrelation function was used to derive an average value and distribution of diffusion coefficients, which were converted to hydrodynamic diameters using the Stokes-Einstein equation for spherical particles. Ultrafiltered concentrates of different $\mathrm{pH}$ were diluted 100 times with the UF permeate $\left(30^{\circ} \mathrm{C}\right)$, which originated from the UF processing of the skim milk. The UF permeate was filtered through $0.22-\mu \mathrm{m}$ Millex filters (Millipore, Billerica, MA) before being used for diluting the samples. The light-scattering measurements were conducted at $30^{\circ} \mathrm{C}$ and initiated 4 min after dilution of the UF concentrate. All measurements were performed in duplicate.

\section{Rheological Measurements}

Small amplitude oscillatory shear measurements and viscometric flow curves of UF concentrate were obtained using a Bohlin C-VOR controlled stress rheometer (Malvern Instruments). The measuring system (C25) consisted of 2 coaxial cylinders (25.0 and 27.5 $\mathrm{mm}$ in diameter). The measuring system was carefully tempered to the measuring temperature $\left(30^{\circ} \mathrm{C}\right)$ before each measurement. Ultrafiltered concentrates of different $\mathrm{pH}$ were tempered for $10 \mathrm{~min}$ in the rheometer before the measurements were performed. To prevent evaporation from the sample, the surface was covered with low-viscosity paraffin oil. The shear measurements were performed at a frequency of $1 \mathrm{~Hz}$ and strain of 0.01 , which was found to be well within the linear viscoelastic region. Results were calculated as arithmetic means of 20 data points measured during $10 \mathrm{~min}$. The viscometry measurements were performed in steady shear rate mode in the shear rate interval from 0.000105 to $1500 / \mathrm{s}$. The instrument was programmed to equilibrate the sample for $3 \mathrm{~min}$ at each shear rate before data was captured. Barnes (1995) discussed the problems with slip artifacts in shear-flow measurements. Slip can result in lower values of viscosity or dramatic drops in the viscosity at low shear stress. Slip artifacts were checked by comparing flow data of measurements performed with the C25 and the C14 measuring bodies (Barnes, 1995). No significant differences were seen in the results when either of the geometries was used. Thus, slip during measurements was excluded. However, care must be taken when measuring the flow behavior of concentrated milk. A rapid drop in viscosity at low shear stress, indicating slip, was seen in pre-experiments when a sample was not given adequate time to equilibrate at each shear rate before data were captured. Both oscillatory and viscometric flow measurements of a sample were performed at least in duplicate. One representative flow curve of each sample is presented in this paper. The kinematic viscosity of UF permeate was measured at $30^{\circ} \mathrm{C}$ with a CannonFenske capillary viscometer (Cannon Instrument Co., State College, PA) following the instructions of the manufacturer. The viscosity of UF permeate was obtained by multiplying the kinematic viscosity by the density of the fluid. The density of UF permeate was measured at $30^{\circ} \mathrm{C}$ with a Paar Physica DMA 58 (Anton Paar, Graz, Austria) following the manufacturer's instructions. 


\section{Transmission Electron Microscopy}

Selected replicas of freeze-fractured UF concentrate of different $\mathrm{pH}$ were examined using transmission electron microscopy. Two preparation techniques were used. In the first technique, UF concentrate was cryoprotected by mixing $2 \mathrm{~mL}$ of sample with $1 \mathrm{~mL}$ of glycerol $(87 \%$, wt/wt) before cryofixation in melting Freon $22\left(-160^{\circ} \mathrm{C}\right)$. Fracture and examination of samples was made as reported by Schrader et al. (1997).

In the second technique, a droplet of UF concentrate was placed on a small gold mesh (Bal-Tec, Witten, Germany). The mesh was then placed between 2 copper plates (Bal-Tec). Both plates were flat but one of them had a small cavity for the sample. This "sandwich" was immediately placed in a JFD 030 Cryo-jet (Balzers, Lichtenstein), and the sample was quickly frozen in the apparatus by a jet of liquid propane $\left(-180^{\circ} \mathrm{C}\right)$. After freezing, the sample was automatically dropped into liquid propane. The sample was then moved to a tank of liquid nitrogen $\left(-120^{\circ} \mathrm{C}\right)$ before the freeze-fracture preparation took place. The samples were fractured in a Balzers BA $360 \mathrm{M}$ unit (Balzers). Further preparation of the samples and examination of replicas were performed according to the method reported by Schrader et al. (1997).

\section{Model Fitting and Statistical Analyses}

The steady shear rate $\eta(\dot{\gamma})$ data were fitted to the Carreau-Yasuda model:

$$
\eta(\dot{\gamma})=\left[1+(\dot{\gamma} \lambda)^{a}\right]^{\frac{n-1}{a}} \cdot\left[\eta_{0}-\eta_{\infty}\right]+\eta_{\infty}
$$

where $\eta_{0}$ is the zero-shear viscosity, $\eta_{\infty}$ is the infiniteshear-rate viscosity, $\lambda$ is the characteristic viscous relaxation time, $a$ is a dimensionless parameter called the "Yasuda-constant," and $n$ is the flow behavior index (Jordens et al., 2000). The data fit to the nonlinear model (Eq. [3]) and statistical analysis of the model fit was made using the NLIN procedure in SAS software version 8.02 (1999-2001, SAS Institute, Inc., Cary, NC). For all data fits, $R^{2}>0.98$.

\section{RESULTS AND DISCUSSION}

\section{Chemical Composition}

All proteins were retained by the membranes during the UF process. This was confirmed by the fact that the UF permeate contained only a small fraction of NPN (results not shown). The ratio between the calculated amounts of whey protein to casein did not differ significantly in the UF concentrate compared with the initial skim milk but was low in both products compared with values in the literature (Walstra and Jenness, 1984).

\section{Flow Curves and Model Fitting}

Flow curves of concentrated milk are often graphically portrayed as plots of applied stress ( $\sigma$; Solanki and Rizvi, 2001) or apparent viscosity $[\eta(\sigma)$; Bienvenue et al., 2003a,b] against linear shear rate. When either of those plots is used, it can be hard to distinguish between Newtonian and shear-thinning regimes. The measurement interval has often been narrower than in our measurements and an apparent yield stress has been determined with the Bingham model (Bienvenue et al., 2003a,b) or the Herschel-Bulkley model (VélezRuiz and Barbosa-Cánovas, 1998). The use of a sensitive instrument and plots such as Figure 1A better revealed the Newtonian regimes and demonstrated that the UF concentrate in our study has no yield stress but a zero-shear viscosity. Although not present, the determination of a yield stress can be useful as it is an engineering reality in industrial processes. We suspect, however, that previous determinations of an apparent yield stress have been strongly influenced by the character of the shear-thinning regimen and the measurement interval of choice. Figure 1A indicates a Newtonian regime at high shear rates. The models previously used for predicting the flow for UF concentrate (powerlaw and Herschel-Bulkley) are not valid for an extended shear rate regime as they do not include the 2 Newtonian regimes.

To determine the volume fraction with Eilers relation (Eq. [1]), it is necessary to determine the viscosity $(\eta)$ of the colloidal suspension and the maximum volume fraction $\left(\Phi_{\max }\right)$ of the colloids. The viscosity of use in relations like Eq. [1] can generally be determined at low, intermediate, or high shear stresses for noninteracting particles (Barnes et al., 1989). However, Eilers originally developed the relation for particles, which only hydrodynamically interact with each other (Eilers, 1941). Thus, the viscosity must be determined at high shear stress, where only hydrodynamic interactions between particles are determined for the viscosity. Generally, $\Phi_{\max }$ has been found to be stress dependent for concentrated shear-thinning suspensions (Barnes et al., 1989). An ordered 3-D structure of the casein micelles in the UF concentrate at low shear stress can be suspected for highly elastic samples. A 3-D structure decreases $\Phi_{\max }$. Thus, the same value for $\Phi_{\max }$ cannot be used for all samples. Hence, if Eq. [1] is to be used, a viscosity at high shear stress must be found. Different ways of determining $\eta$ at high shear stress for systems of concentrated milk have been used. Snoeren et al. (1982) plotted the apparent viscosity, $\eta(\dot{\gamma})$, as a function 

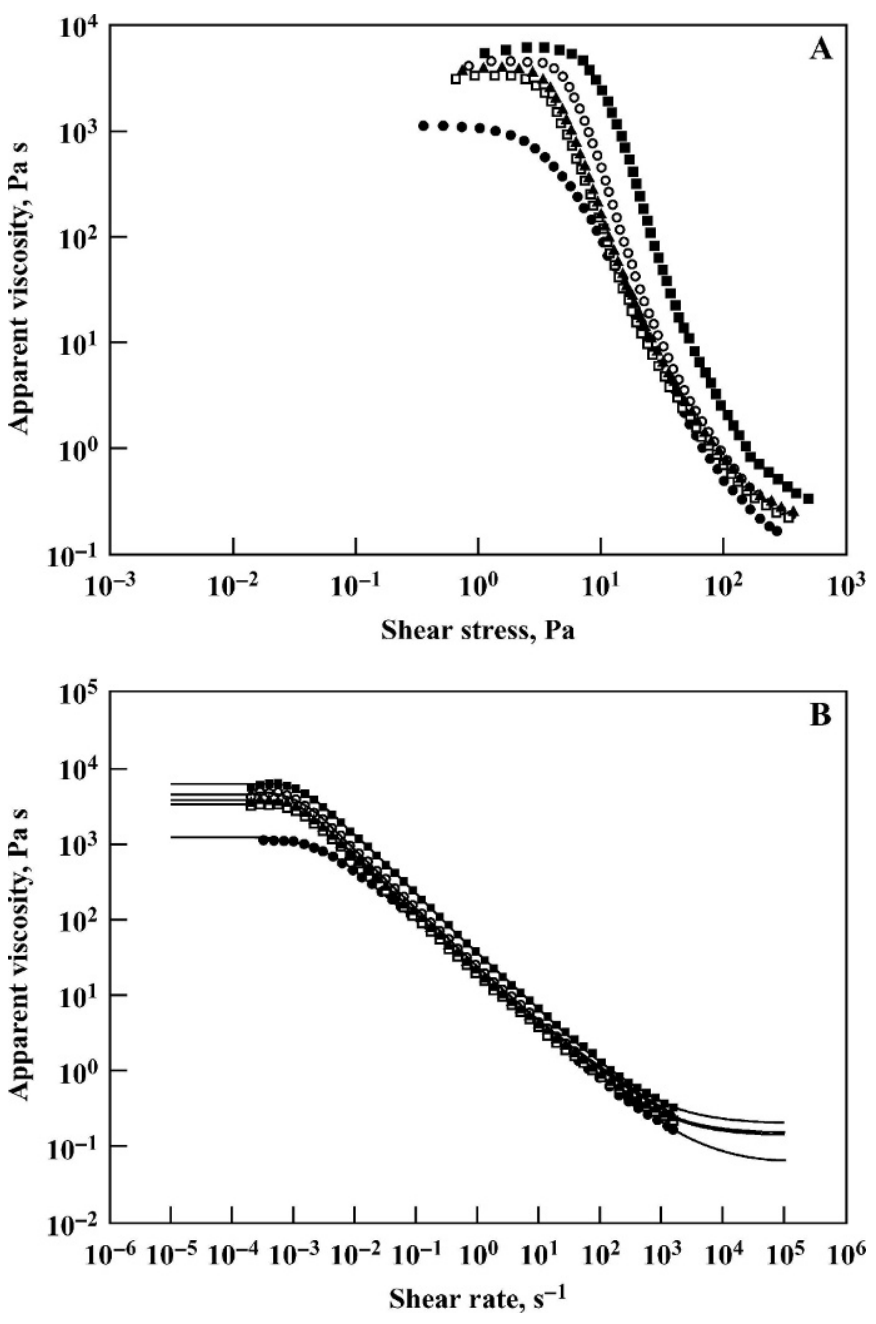

Figure 1. Apparent viscosity as a function of shear stress (A) and shear rate (B) at $30^{\circ} \mathrm{C}$ for UF concentrates with no salt $(-0.33 \mathrm{~mol} /$ $\mathrm{kg}$ of $\mathrm{NaCl}(\bigcirc), 0.66 \mathrm{~mol} / \mathrm{kg}$ of $\mathrm{NaCl}(\square), 0.33 \mathrm{~mol} / \mathrm{kg}$ of $\mathrm{KCl}(\square)$, and $0.66 \mathrm{~mol} / \mathrm{kg}$ of $\mathrm{KCl}(\mathbf{\Delta})$. Lines in (B) indicate the fit to the CarreauYasuda model.

of the inversed shear rate $\left(\dot{\gamma}^{-1}\right)$. The intercept was then used to determine a value for $\eta$ at infinite high shear rates $\left(\eta_{\infty}\right)$. Hallström and Dejmek (1988) used $\eta$ at a constant shear stress of $500 \mathrm{~Pa}$ for the calculations in Eq. [1]. Our results showed that even at the highest possible shear stress, the viscosity had not reached $\eta_{\infty}$ (Figure 1A). Therefore, the model of Carreau-Yasuda (Eq. [3]) was used to fit the shear flow data and to determine $\eta_{\infty}$. In the model fit, $\mathrm{R}^{2}$ values were never less than 0.98. The fit of the flow data to the CarreauYasuda model is shown for some of the samples in Figure 1B. This model fits the data in the 2 Newtonian regimens. When determining the parameters of the Carreau-Yasuda model for a set of data, there is a risk that all or some of the 5 parameters strongly correlate with each other. In our flow curve fittings, the correla-
Table 2. Values of parameters used in the calculations of volume fraction of casein $\left(\Phi_{\text {casein }}\right)$ and voluminosity of casein $\left(\nu_{\text {casein }}\right)$.

\begin{tabular}{|c|c|c|}
\hline & Symbol & Value \\
\hline Maximum volume fraction ${ }^{1}$ & $\Phi_{\max }$ & 0.79 \\
\hline Viscosity of serum, $\mathrm{Pa} \cdot \mathrm{s}$ & $\eta_{s}$ & 0.944 \\
\hline Voluminosity of native whey protein, ${ }^{1} \mathrm{~mL} / \mathrm{g}$ & $\nu_{n w}$ & 1.07 \\
\hline Concentration of casein, $\%$ (wt/wt) & $C_{\text {casein }}$ & 19.5 \\
\hline Concentration of whey protein, $\%$ (wt/wt) & $C_{w h e n}$ & 3.79 \\
\hline Density of UF concentrate, $\mathrm{g} / \mathrm{mL}$ & $\rho$ & 1.056 \\
\hline
\end{tabular}

${ }^{1}$ According to Snoeren et al., 1982.

${ }^{2}$ Kjeldahl analysis.

tion coefficient between $\eta_{\infty}$ and any of the other parameters was never higher than 0.508 and the standard deviation of $\eta_{\infty}$ was always below $12.1 \%$.

With $\eta_{\infty}$ of samples and the values of the parameters in Table 2 , the volume fraction $\left(\Phi_{\text {casein }}\right)$ and voluminosity of casein $\left(\nu_{\text {casein }}\right)$ was calculated with Eq. [1] and Eq. [2]. The value of $\Phi_{\max }$ in Eq. [1] was found to be 0.79 for concentrated skim milk (Snoeren et al., 1982). The broad size distribution of the particles in milk contributes to this relatively large value. The change in voluminosity of whey proteins due to increased ionic strength by $\mathrm{NaCl}$ or $\mathrm{pH}$ (Boulet et al., 1998) has been found to be very small. Thus, we assumed for our calculations that the voluminosity of whey proteins $\left(\nu_{n w}\right.$ and $\nu_{d w}$ ) did not change.

\section{Influence of Salts}

In agreement with previous results (Le Graët and Gaucheron, 1999), addition of $\mathrm{NaCl}$ decreased $\mathrm{pH}$ of the UF concentrate (Table 3 ). In addition, $\mathrm{KCl}$ decreased the $\mathrm{pH}$ of UF concentrate but not as effectively as did $\mathrm{NaCl}$. All samples (Table 3) showed the same type of flow pattern; a Newtonian regime at low shear stress, a shear-thinning regime at intermediate shear stress, and indications of a second Newtonian regime at very high shear stress (Figure 1). The apparent viscosity at all levels of shear stress generally increased when either of the salts was added to the UF concentrate.

Table 3. Variation in $\mathrm{pH}$, volume fraction of casein $\left(\Phi_{\text {casein }}\right)$, and voluminosity of casein $\left(\nu_{\text {casein }}\right)$ at different concentrations $(c)$ of $\mathrm{NaCl}$ and $\mathrm{KCl}$ in UF concentrate.

\begin{tabular}{lllll}
\hline Salt & $\begin{array}{c}c \\
(\mathrm{~mol} / \mathrm{kg})\end{array}$ & $\mathrm{pH}$ & $\Phi_{\text {casein }}$ & $\begin{array}{c}\nu_{\text {casein }} \\
(\mathrm{mL} / \mathrm{g})\end{array}$ \\
\hline$\overline{\mathrm{NaCl}}$ & - & 6.51 & 0.635 & 3.085 \\
$\mathrm{NaCl}$ & 0.33 & 6.40 & 0.684 & 3.321 \\
$\mathrm{KCl}$ & 0.66 & 6.33 & 0.694 & 3.370 \\
$\mathrm{KCl}$ & 0.33 & 6.46 & 0.683 & 3.316 \\
\hline
\end{tabular}



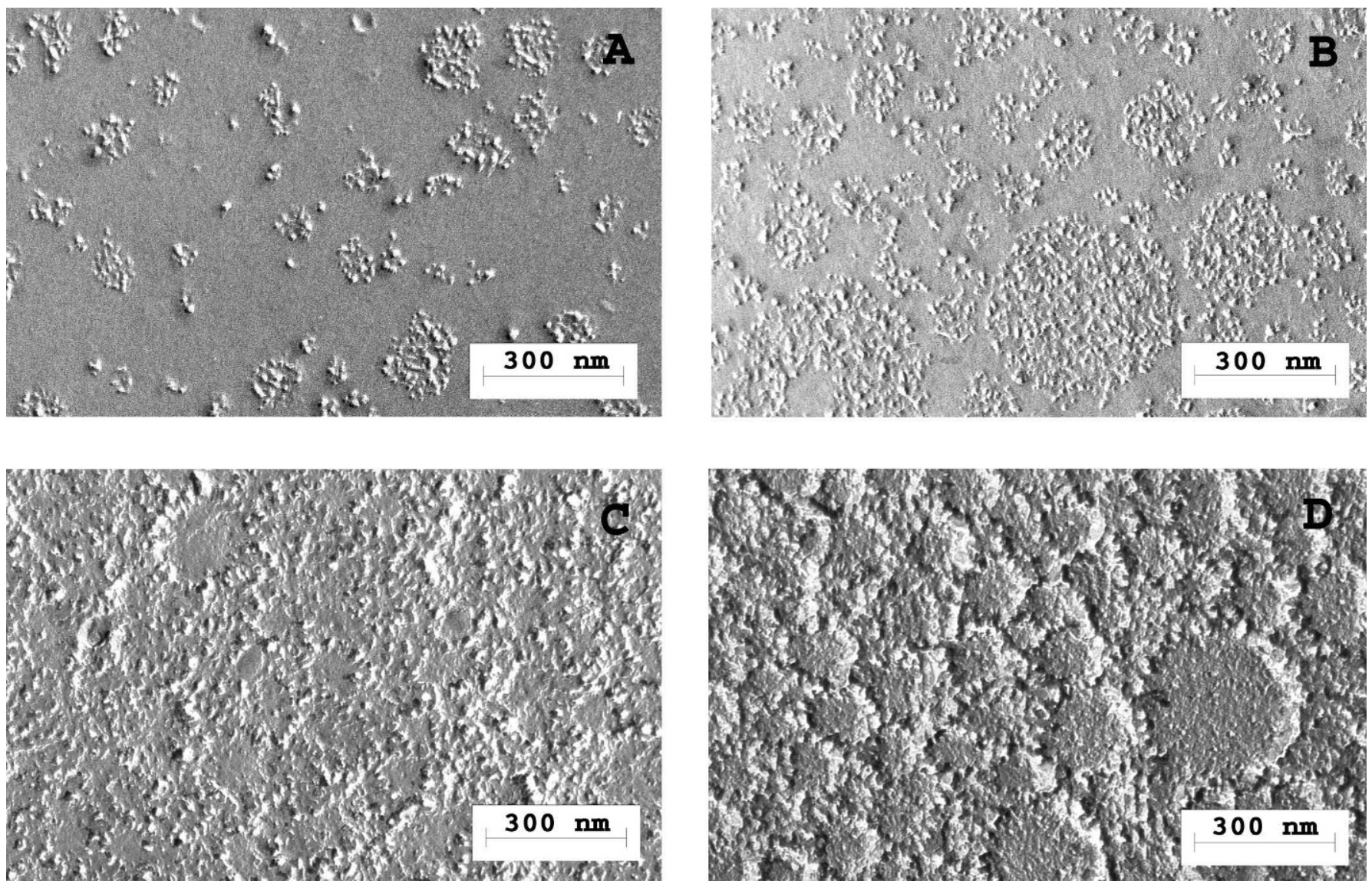

Figure 2. Transmission electron micrographs of replicas from freeze-fractured UF concentrate with no $\mathrm{NaCl}$ at $\mathrm{pH} 6.51$ (A and C) and $0.66 \mathrm{~mol} / \mathrm{kg}$ of $\mathrm{NaCl}$ at $\mathrm{pH} 6.33$ (B and D). Samples in (A) and (B) were prepared by the method described by Schrader et al. (1997), and samples in (C) and (D) were prepared using the Cryo-jet. Samples were equilibrated at $30^{\circ} \mathrm{C}$ for $24 \mathrm{~h}$ before freeze-fracture preparation.

The calculated values of $\Phi_{\text {casein }}$ and $\nu_{\text {casein }}$ at different concentrations of $\mathrm{NaCl}$ or $\mathrm{KCl}$ are presented in Table 3. Reported values of $\nu_{\text {casein }}$ vary in the literature according to the method used for measurement. For native bovine casein micelles, microscopy and ultracentrifugation experiments have given values for $\nu_{\text {casein }}$ of approximately $2.2 \mathrm{~cm}^{3} / \mathrm{g}$, and methods based on hydrodynamic methods (i.e., light scattering and viscometry) have given $\nu_{\text {casein }}$ values of approximately $3.9 \mathrm{~cm}^{3} / \mathrm{g}$ (Walstra, 1979).

When cryoprotected samples were prepared by cryofixation in melted Freon 22 for transmission electron microscopy (Figure 2, A and B), structures interpreted as casein micelles with their own distinct integrity could be observed (Schrader et al., 1997). Because this preparation technique includes a dilution of the concentrate with glycerol before freezing, a reflection of the close packing of the casein micelles in the UF-concentrate is not possible, and there is a risk for dehydration of the proteins due to the glycerol, a preparation technique including rapid freezing of undiluted UF concen- trated in a Cryo-jet was also used. The second type of preparation would better reveal the close packing of the casein micelles in the samples. Moreover, possible artifacts due to addition of glycerol would be eliminated. However, because the preparation with the Cryo-jet has not previously been used for milk concentrates, the method including dilution of the sample in glycerol was included for comparison (Figure 2, A and B). Microstructure of casein micelles with clear integrity was not seen on the micrographs of replicas of freeze-fractured UF concentrate prepared with the Cryo-jet (Figure 2, $\mathrm{C}$ and $\mathrm{D})$. On the contrary, smaller rough structures, which form bands or even webs, were apparent. When comparing the micrographs of the 2 preparation techniques, the size of the smooth regions in Figure 2, C and $\mathrm{D}$ were roughly the same as the size of the casein micelles in Figure 2, A and B. The small rough structures forming the bands in Figure 2, C and D were of the same size as the rough structures on the surface of the casein micelles in Figure 2, A and B. This could indicate that when samples are frozen with the Cryo- 

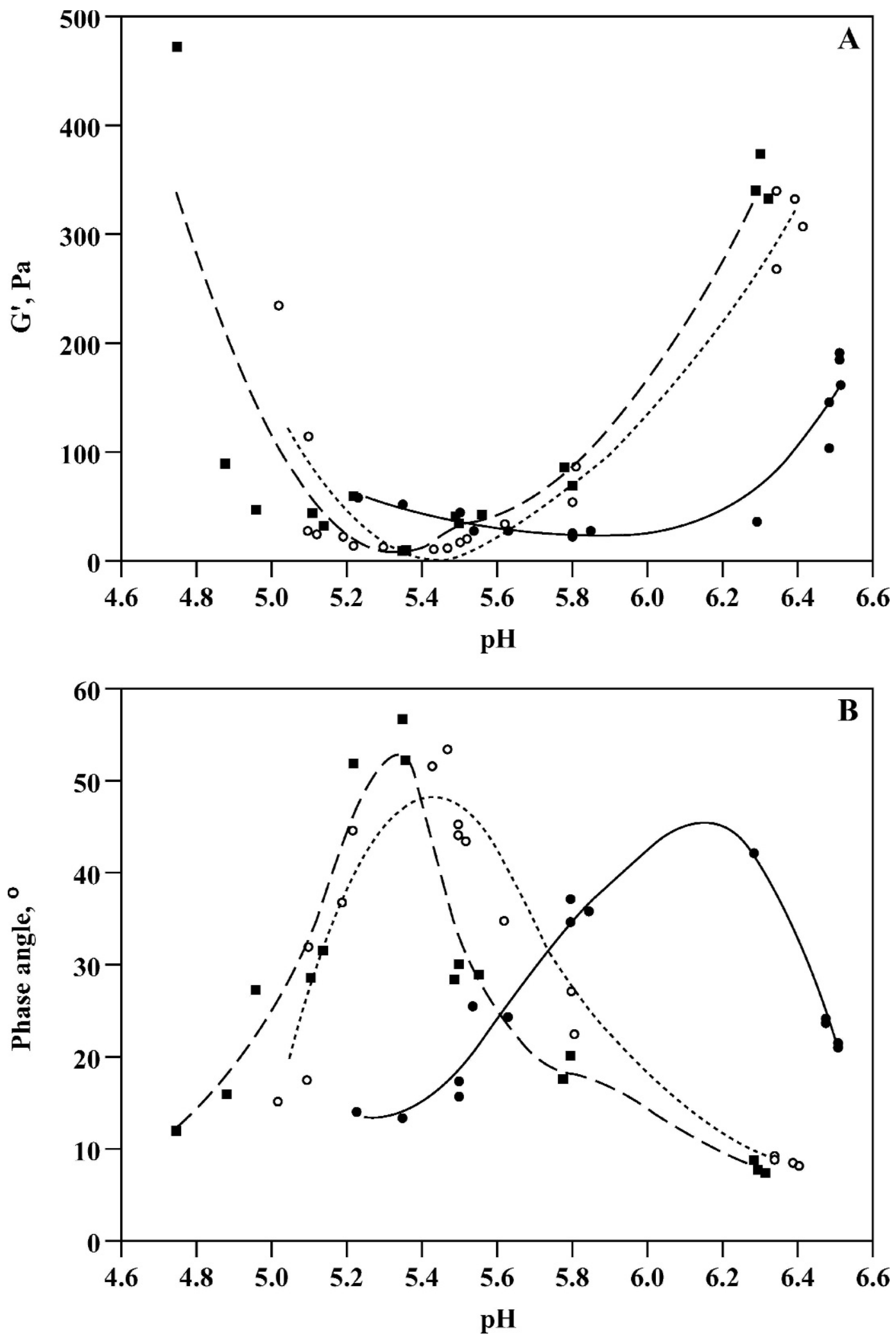

Figure 3. Changes in elastic modulus (A) and phase angle (B) of UF concentrate due to different $\mathrm{pH}$ and no salt ( $)$, $0.33 \mathrm{~mol} / \mathrm{kg}$ of $\mathrm{NaCl}(\mathrm{O})$, and $0.66 \mathrm{~mol} / \mathrm{kg}$ of $\mathrm{NaCl}(\mathbf{\square})$. Small amplitude oscillatory shear measurements were performed at $30^{\circ} \mathrm{C}, 24 \mathrm{~h}$ after addition of glucono- $\delta$-lactone and $\mathrm{NaCl}$. Lines are guides to the eye. 


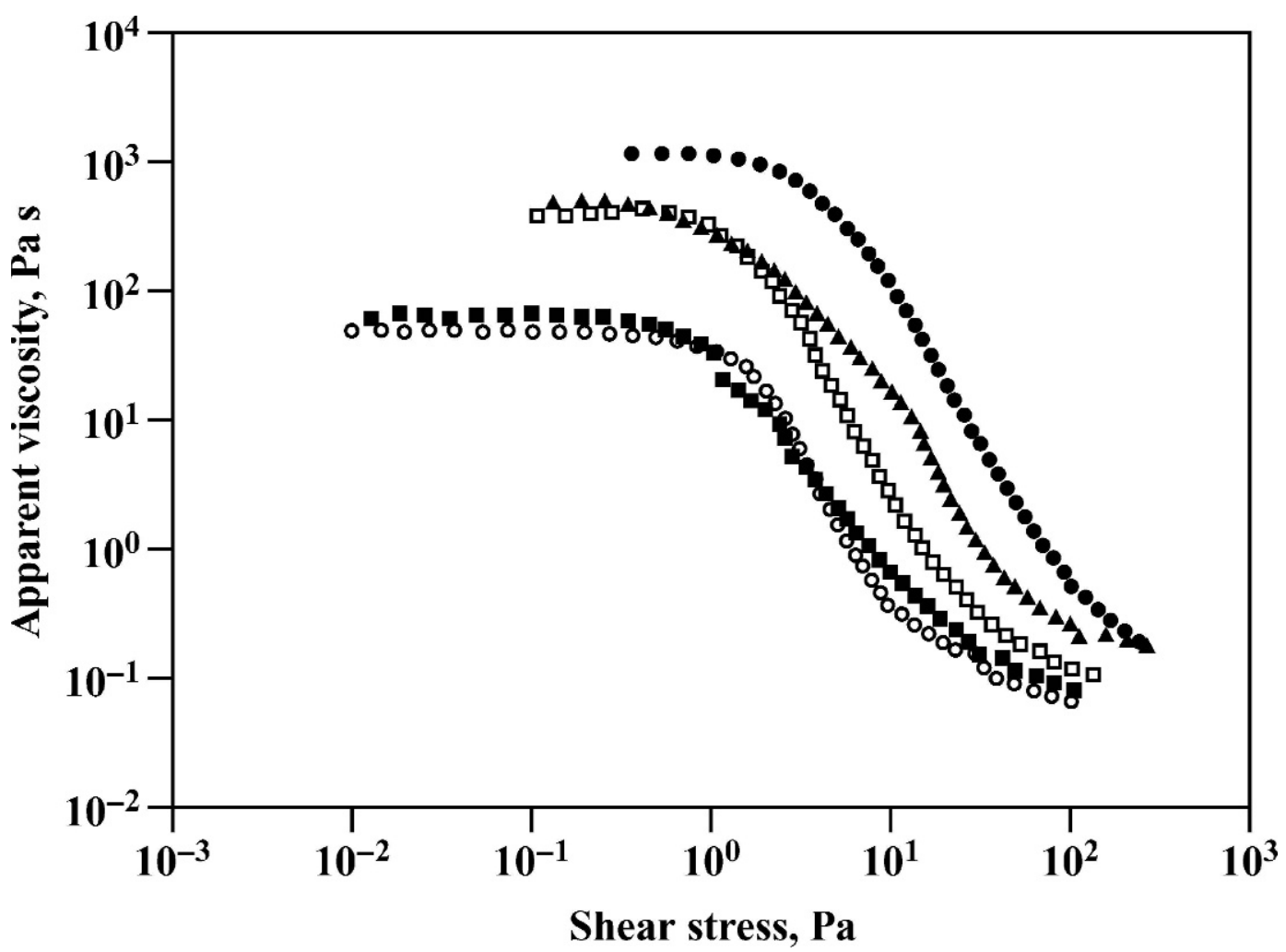

Figure 4. Apparent viscosity as function of shear stress for UF concentrate at pH $6.51(\bullet), 6.15(\bigcirc), 5.83(\square), 5.52(\square)$, and $5.20(\boldsymbol{\Delta})$ at $30^{\circ} \mathrm{C}$.

jet and then fractured, the samples can be fractured not only between but also within micelles. The fracture of the interior of micelles is represented by the areas with smoother topography and the small rough structures represent fractures through micelle surfaces. Figure 2, panels $\mathrm{C}$ and $\mathrm{D}$ show how closely packed the casein micelles were in the UF concentrate. It is hard to distinguish a difference in the size of the casein micelles due to addition of $\mathrm{NaCl}$ in Figure 2, A and $\mathrm{B}$. However, observation of Figures $2 \mathrm{C}$ and $2 \mathrm{D}$ reveals that the rough structures are larger when $\mathrm{NaCl}$ has been added to the UF concentrate. It has been discussed previously whether the rough structures represent submicelles (Walstra, 1999) or an uneven surface of the casein micelles (Dalgleish et al., 2004). Irrespective of this debate, we suggest that if these smaller structures, as parts of the casein micelles, increase in size due to addition of $\mathrm{NaCl}$, then the size of the casein micelles also increases.

The small amplitude oscillatory shear measurements exhibit an increasing elastic modulus (Figure 3A) when $\mathrm{NaCl}$ is added to the UF concentrate at native $\mathrm{pH}$. A high elastic modulus indicates a high level of interaction between casein micelles, providing a high degree of elastic properties to the UF concentrate. Increasing ionic strength in dispersions of electrostatic stabilized colloids is known to shield the charges on the particle surface and decrease the thickness of the electrical double layer (Walstra and Jenness, 1984; Hunter, 1993). This leads to increased attractive interactions between colloids. However, after addition of $\mathrm{NaCl}$, the casein micelles are still effectively prevented from aggregating through steric stabilization due to the functional properties of $\kappa$-casein. In milk, addition of monovalent cations also affects the internal structure of casein micelles. This has been explained by exchange between the added monovalent cations $\left(\mathrm{Na}^{+}\right)$and divalent cations $\left(\mathrm{Ca}^{2+}\right)$, or protons attached to the phosphoseryl residues of the caseins (Grufferty and Fox, 1985; Le Graët and Gaucheron, 1999). Because $\mathrm{Ca}^{2+}$ is an important component in the structure of calcium phosphate clusters that contribute to the rigidity of the casein micelle, addition of $\mathrm{NaCl}$ should result in increased micelle size and increased volume fraction (Table 3) of casein in the UF concentrate. By knowing a sufficient number of particle size classes of casein micelles from the dynamic light scattering measurements and the volume fraction of casein (Table 3) calculated by the Eilers relation (Eq. [1]), it is possible to estimate the mean free distance $(z)$ between the casein micelles in the UF concentrate (Walstra and Jenness, 1984). Such a calculation gives a $z$ value of $6.8 \pm 0.2 \mathrm{~nm}$ between 


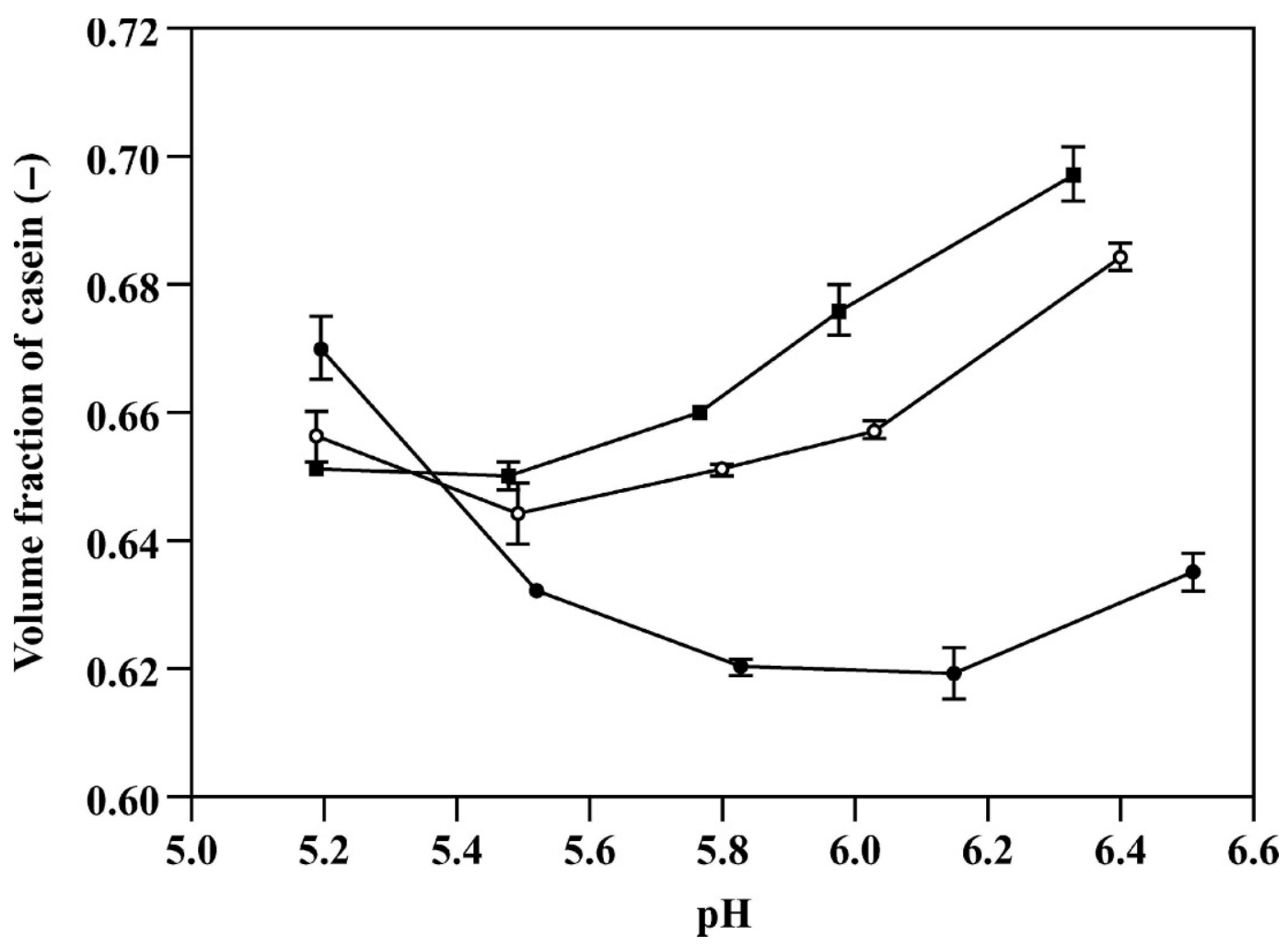

Figure 5. Alterations in calculated values of volume fraction of casein, $\Phi_{\text {casein }}$, in UF concentrate due to changed pH for samples with no salt $(-), 0.33 \mathrm{~mol} / \mathrm{kg}$ of $\mathrm{NaCl}(\bigcirc)$, and $0.66 \mathrm{~mol} / \mathrm{kg}$ of $\mathrm{NaCl}(\mathbf{\square})$. Calculations of $\Phi_{\text {casein }}$ were performed with Eq. [1] and Eq. [2] with estimated values of $\eta_{\infty}$ (Eq. [3]) and parameters in Table 2.

the casein micelles in UF concentrate at $\mathrm{pH}$ 6.51. In undiluted skim milk, $z$ is reported to be $240 \mathrm{~nm}$ (Walstra and Jenness, 1984). In the sample with $0.66 \mathrm{M} \mathrm{NaCl}$, $z$ was calculated to be $2.8 \pm 0.3 \mathrm{~nm}$. These approximate calculations of $z$ give indications of how closely packed the casein micelles are in the UF concentrate with such a high protein concentration, and how addition of $\mathrm{NaCl}$ forces the casein micelles even closer together. Although the micelles are sterically stabilized by $\kappa$-casein, the compression of the electrical double layer and interactions over shorter distances by addition of $\mathrm{NaCl}$ induce larger attractive interactions. This effect is reflected in the increased elastic modulus of the UF concentrate when $\mathrm{NaCl}$ is added (Figure 3A). It can be assumed that if the protein concentration of the UF concentrate was decreased, the effects of $\mathrm{NaCl}$ on casein micelle size would be the same but the effects on the rheological properties would be smaller due to interactions over longer distances between casein micelles.

\section{Influence of $\mathrm{pH}$}

Samples at different $\mathrm{pH}$ (Figure 4) generally exhibited the same type of flow behavior as samples with addition of salt (Figure 1). For the UF concentrate at $\mathrm{pH} 5.2$, a shift in the slope of the curve in the shearthinning region made the fit of viscosity $\eta(\dot{\gamma})$ to the Carreau-Yasuda model at lower shear rates inadequate, but it was acceptable at higher shear rates. At $\mathrm{pH} 5.2$, the UF concentrate was close to the $\mathrm{pH}$ of acid coagulation and the change of slope in the shear-thinning region is therefore assumed to be caused by the same mechanisms suggested for stirred-acid casein gels (Knudsen et al., 2005). From $\eta_{\infty}$ of the Carreau-Yasuda model and parameters in Table 2, Eq. [1] and [2] were used to calculate $\Phi_{\text {casein }}$ and $\nu_{\text {casein }}$ of samples with different $\mathrm{pH}$ (6.5 to 5.2). Figure 5 and Figure 6 show the change in $\Phi_{\text {casein }}$ and $\nu_{\text {casein }}$ in the investigated $\mathrm{pH}$ interval. When $\mathrm{pH}$ is decreased, $\nu_{\text {casein }}$ first decreases and then increases again when the $\mathrm{pH}$ approaches the interval at which acid-induced aggregation occurs.

At pH 5.8 (Figure 7, A and C), the small rough structures forming the web in the microstructure appeared to be the same size or slightly smaller as at $\mathrm{pH} 6.5$ (Figure 2A). However, near the acid-coagulation $\mathrm{pH}$ (pH 5.2; Figure 7, B and D), the small rough structures are larger. 


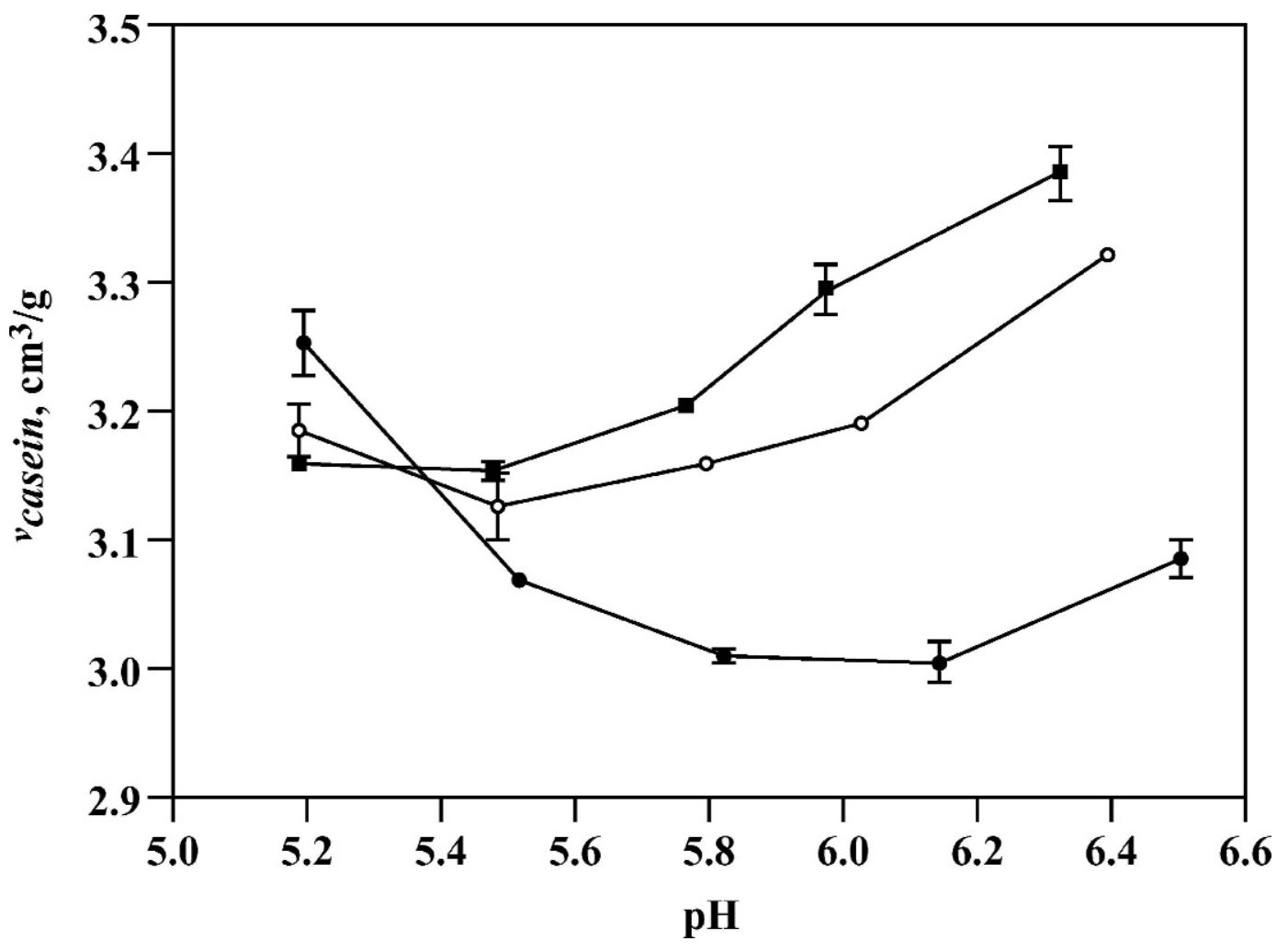

Figure 6. Alterations in calculated values of voluminosity of casein, $\nu_{\text {casein }}$, in UF-concentrate due to changed $\mathrm{pH}$ for samples with no salt $(\circlearrowleft), 0.33 \mathrm{~mol} / \mathrm{kg}$ of $\mathrm{NaCl}(\bigcirc)$, and $0.66 \mathrm{~mol} / \mathrm{kg}$ of $\mathrm{NaCl}(\mathbf{\square})$. Calculations of $\nu_{\text {casein }}$ were performed with Eq. [1] and Eq. [2] with estimated values of $\eta_{\infty}$ (Eq. [3]) and parameters in Table 2.

The dramatic drop in elastic modulus for samples when $\mathrm{pH}$ is decreased from $\mathrm{pH} 6.5$ to 5.8 indicates decreased interactions between casein micelles (Figure $3 \mathrm{~A})$. At moderate decrease of $\mathrm{pH}$, not only is the isoelectric point of single amino acids on $\kappa$-casein reached, but also ion strength is increased and colloidal calcium phosphate of the casein micelle is dissolved. As mentioned before, increased ion strength compresses the electrical double layer and screens charges on $\kappa$-casein. This leads to partial collapse of the $\kappa$-casein layer (de Kruif, 1997). These factors should lead to increased attractions between micelles. However, according to our results, moderate decrease of $\mathrm{pH}$ also leads to a smaller $\nu_{\text {casein }}$ of the casein micelle (Figure 6). Part of this effect can be attributed to the partial collapse of the $\kappa$-casein layer. The decreased $\nu_{\text {casein }}$ gives the micelles more space and they interact over longer distances, where the interactions are weaker. This could explain the decrease in elastic modulus when $\mathrm{pH}$ is decreased to the interval of 6.1 to 5.8. Thus, decreasing $\mathrm{pH}$ of skim milk before the UF process would be useful for saving energy for pumps in the UF process, and would make it possible to obtain a higher casein concentration in the endproduct.
At $\mathrm{pH} 5.2$, the caseins of samples without $\mathrm{NaCl}$ were partially aggregated. This can be concluded from the high elastic modulus (Figure 3A) and indications in the micrographs (Figure 6). Because of the aggregation, the total volume fraction of particles is increased (Hunter, 1993) and the sample at $\mathrm{pH} 5.2$ showed a larger value for $\nu_{\text {casein }}$ (Figure 6).

All the observed changes occurring because of varying $\mathrm{pH}$, except the increase at $\mathrm{pH} 5.2$ in the elastic modulus (Figure 3a), can be explained by changed distances and therefore changed interactions between the casein micelles. If a UF concentrate with a lower concentration were used in our study, the changes in $\mathrm{G}^{\prime}$ would presumably be smaller when going from $\mathrm{pH} 6.5$ to 5.5 because the casein micelles interact over longer distances.

\section{Influence of $\mathrm{pH}$ in Combination with $\mathrm{NaCl}$}

The changing casein micelle size, measured by dynamic light scattering, for samples of different $\mathrm{NaCl}$ concentrations in the $\mathrm{pH}$ range 6.5 to 5.2 is shown in Figure 8 . When adjusting $\mathrm{pH}$ for samples containing $\mathrm{NaCl}$, the z-average of the casein micelles is smallest in the middle of the investigated $\mathrm{pH}$ interval. The in- 

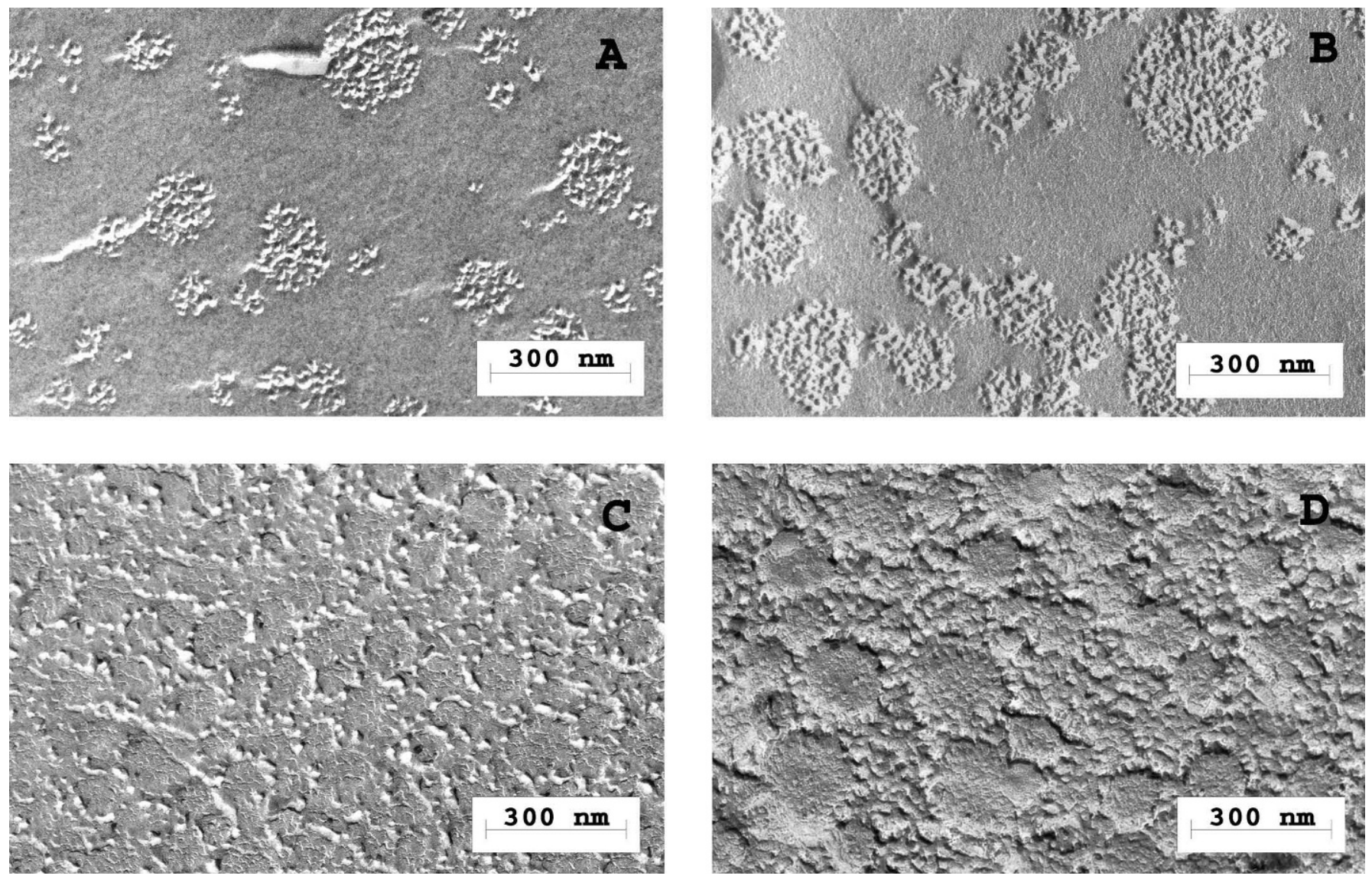

Figure 7. Transmission electron micrographs of replicas from freeze-fractured UF concentrate of $\mathrm{pH} 5.82(\mathrm{~A}$ and $\mathrm{C})$ and $\mathrm{pH} 5.21(\mathrm{~B}$ and D). Samples in (A) and (B) were prepared by the method described by Schrader et al. (1997), and samples in (C) and (D) were prepared using the Cryo-jet. Samples were equilibrated at $30^{\circ} \mathrm{C}$ for $24 \mathrm{~h}$ before freeze-fracture preparation.

creased z-average at lower $\mathrm{pH}$ is probably due to acidinduced aggregation of casein micelles. When diluting the UF concentrate with UF permeate, it is impossible to separate aggregated casein micelles without influencing the size of the single casein micelle. In UF concentrate without $\mathrm{NaCl}$, z-average is continuously increasing when decreasing $\mathrm{pH}$. Thus, the $\mathrm{pH}$ of acidinduced aggregation is lower for samples containing $\mathrm{NaCl}$. For diluted unconcentrated skim milk $\left(30^{\circ} \mathrm{C}\right)$ without added $\mathrm{NaCl}$, de Kruif (1997) has shown that the particle size, measured by dynamic light scattering, was constant between $\mathrm{pH} 6.7$ and 5.0 but abruptly increased at $\mathrm{pH}$ 5.0.

The measurements of UF concentrates with different $\mathrm{NaCl}$ concentrations revealed that the elastic modulus first decreased from a high level at $\mathrm{pH} 6.5$ toward much lower values in the middle of the $\mathrm{pH}$ interval under investigation (Figure 3A). Samples of pH 6.5 to 6.2 containing $\mathrm{NaCl}$ had high elastic moduli. The low value of the phase angle of samples of $\mathrm{pH} 6.5$ to 6.2 indicated that the relation between viscous elements of the fluid and interactions of elastic character is large (Figure 3B). The rapid increase in elastic modulus and decreased phase angle in the lower $\mathrm{pH}$ range is a result of increased attractive interactions due to acid-induced aggregation of casein micelles. The acid-induced coagulation occurred very sharply at a certain $\mathrm{pH}$ and it was difficult to prepare samples that were not too stiff for applying in the rheometer but elastic enough to capture the increase of the elastic modulus.

The results showed that $\mathrm{NaCl}$ has a specific influence during acidification of casein. It has been suggested that $\mathrm{NaCl}$ prevents the collapse of the outer hairy layer of $\kappa$-casein on the casein micelles to a certain degree during acidification and restores the steric repulsion between casein micelles at lower $\mathrm{pH}$ (Schkoda et al., 1999). This pushes the acid-induced aggregation of casein micelles toward lower $\mathrm{pH}$. This was confirmed by our dynamic light scattering measurements (Figure 8). As previously discussed, the increase in $\nu_{\text {casein }}$ and decrease in distance between the micelles caused by addition of $\mathrm{NaCl}$ seemed to result in increased interactions, 


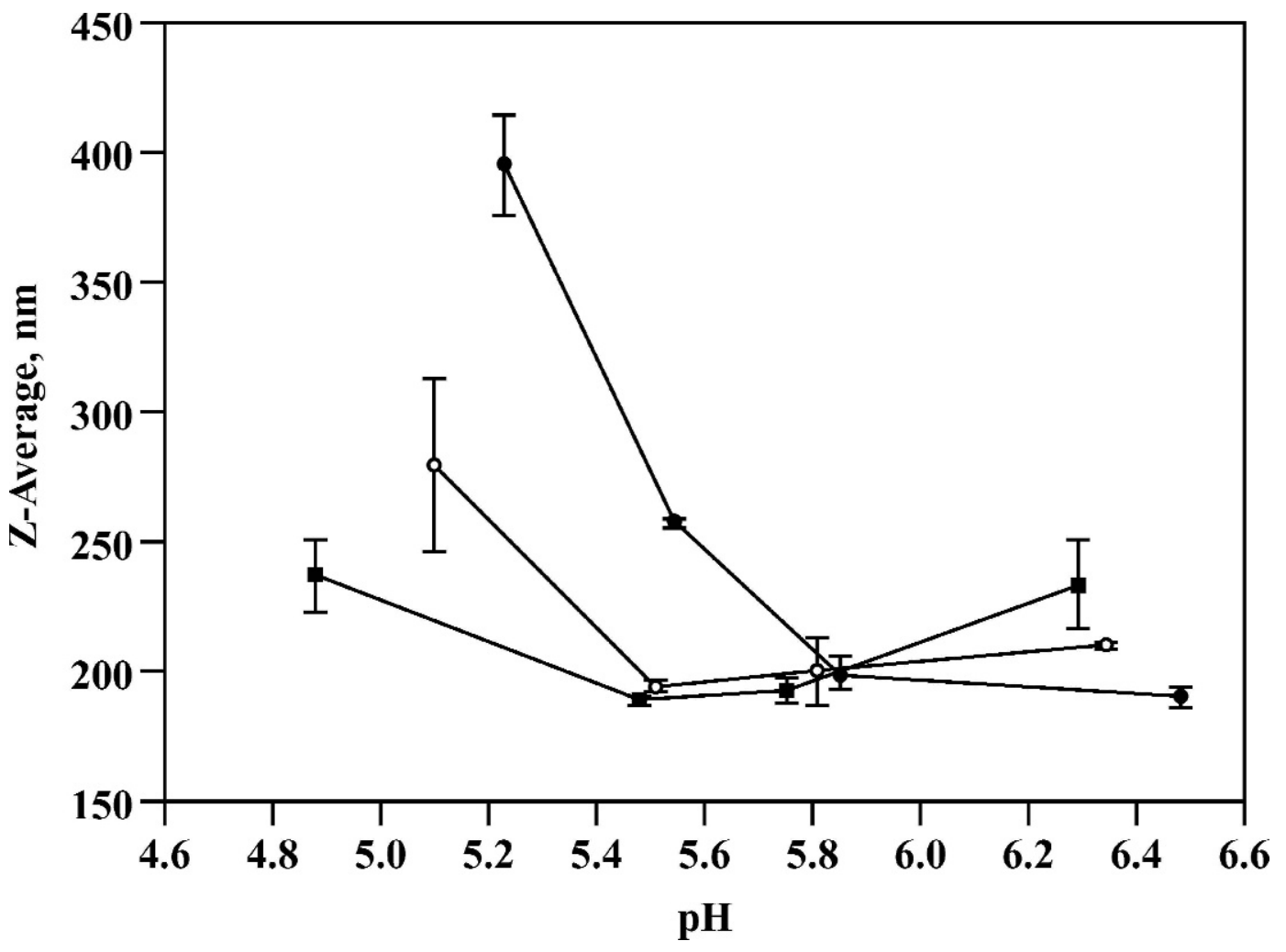

Figure 8. Z-average measured by dynamic light scattering as a function of $\mathrm{pH}$ for particles in UF concentrate with no salt (-), $0.33 \mathrm{~mol} /$ $\mathrm{kg}$ of $\mathrm{NaCl}(\mathrm{O})$, and $0.66 \mathrm{~mol} / \mathrm{kg}$ of $\mathrm{NaCl}(\mathbf{\square})$. Samples of UF concentrate were dissolved in UF permeate 4 min before the measurements at $30^{\circ} \mathrm{C}$ were initiated.

as indicated by the elastic modulus (Figure 3A). This could be the case in the higher $\mathrm{pH}$ range. However, the flow behavior of samples at $\mathrm{pH} 5.5$ (Figure 9) indicated a transition point, at which a collapse of the hairy layer of $\kappa$-casein and decreased steric repulsion is of importance to the attractive interactions between micelles. At $\mathrm{pH} 5.5, \nu_{\text {casein }}$ is still largest for samples containing $\mathrm{NaCl}$ (Figure 6). This is calculated from $\eta_{\infty}$ and correlates with the apparent viscosity at high shear stresses for the 3 samples shown in Figure 9. At low shear stress, the viscosity of the Newtonian regime is determined by interactions between micelles. Thus, there is a higher level of attractive interactions between micelles in the UF concentrate with no $\mathrm{NaCl}$. This is the case, although the micelles in this sample interact over longer distances, i.e., have smaller $\nu_{\text {casein }}$ compared with the other 2 samples (Figure 9). This may be explained by a larger degree of collapse of the hairy layer of $\kappa$-casein on the casein micelles of the UF concentrate with no added $\mathrm{NaCl}$. This causes the flow curve of the UF concentrate without $\mathrm{NaCl}$ to cross the other 2 flow curves.

\section{CONCLUSIONS}

The rheological properties of UF concentrate with high protein concentration show a large dependence on the $\mathrm{pH}(6.5$ to 5.2$)$ and the concentration of $\mathrm{NaCl}(0$ to $0.66 \mathrm{~mol} / \mathrm{kg}$ ). The UF concentrates show a Newtonian regime at low shear rates followed by a shear-thinning regime and the beginning of a second Newtonian regime at higher shear rates. Through model fitting of the flow curves to the Carreau-Yasuda model, it was possible to estimate the viscosity $\left(\eta_{\infty}\right)$ of the UF concentrates at infinite high shear rates. With values of $\eta_{\infty}$ and Eilers relation, the voluminosity of casein $\left(\nu_{\text {casein }}\right)$ was calculated at different $\mathrm{pH}$ and $\mathrm{NaCl}$ concentrations. Values of $\nu_{\text {casein }}$ and the z-average of the casein micelles, measured by dynamic light scattering, increased due to addition of $\mathrm{NaCl}$. This is explained by exchange of $\mathrm{Ca}^{2+}$ bound to the casein micelle matrix with $\mathrm{Na}^{+}$. Because $\mathrm{Ca}^{2+}$ is important to the structure of the micelle, the size of the micelle is believed to increase upon addition of $\mathrm{NaCl}$. The increased size of the casein micelles forces the micelles to interact over shorter distances. This, in combination with increased shielding of charges on the caseins, increases the attractive interactions between the micelles. The occurrence of some aggregation of micelles cannot be excluded when $\mathrm{NaCl}$ is added to the UF concentrate. This is observed as an increased elastic modulus in small amplitude oscillatory measurements of UF concentrate with added $\mathrm{NaCl}$. Decreasing $\mathrm{pH}$ 


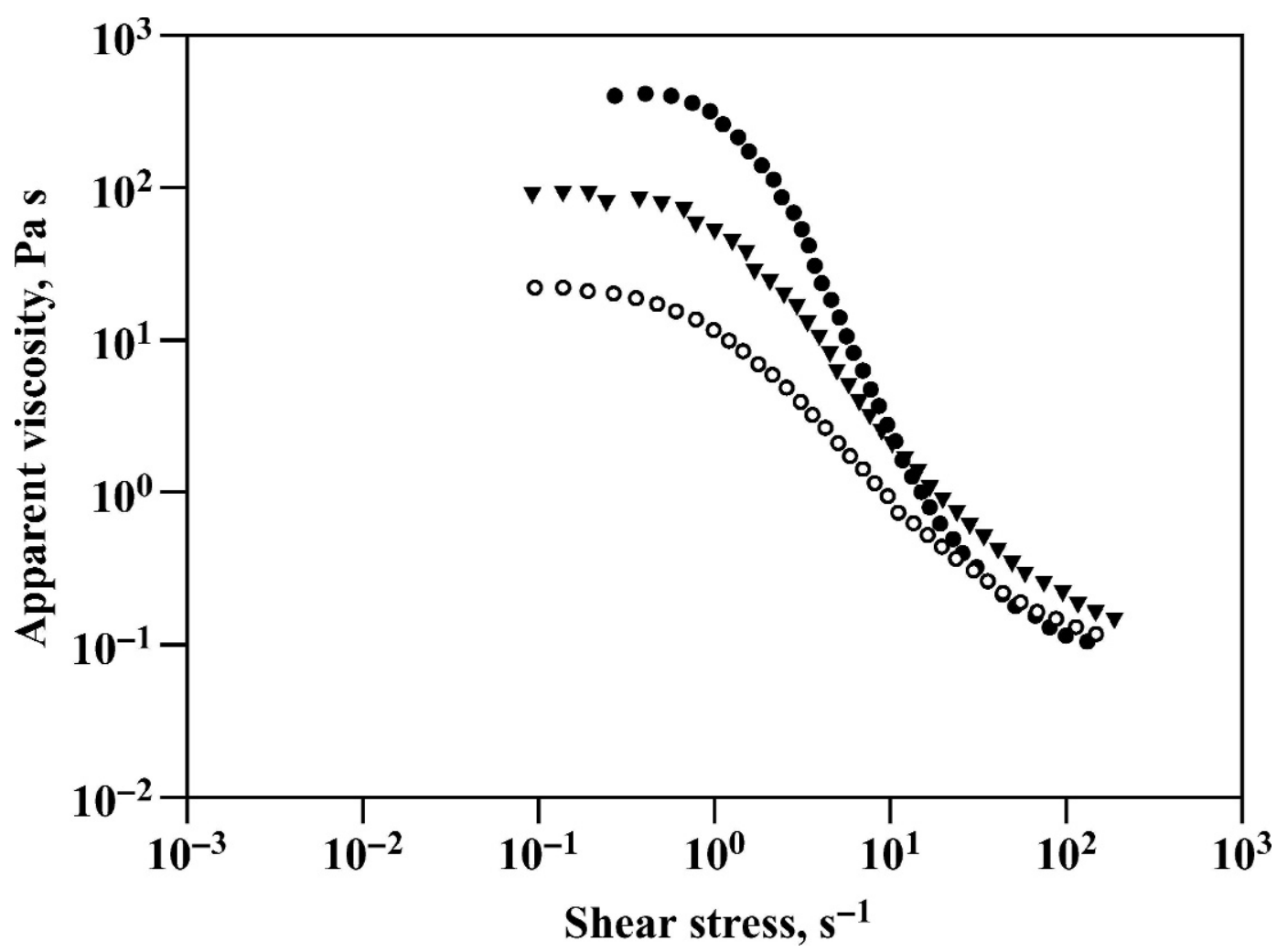

Figure 9. Flow curves of UF-concentrate (pH 5.5) with no salt presented as apparent viscosity as function of shear stress.

from 6.5 to 5.8 decreased $\nu_{\text {casein }}$ and elastic modulus. The lower elastic modulus is believed to be a result of the decreased $\nu_{\text {casein }}$, which caused the micelles to interact over longer distances. At pH 5.5 to 5.2 , the collapse of the hairy layer of $\kappa$-casein on the surface of the casein micelles is evident in the samples with no added $\mathrm{NaCl}$. This increases attractive interactions between the casein micelles although the $\nu_{\text {casein }}$ is lower than at $\mathrm{pH}$ 6.5. This confirms the importance of the $\kappa$ caseins for sterically stabilizing the casein micelles from aggregating. Presence of $\mathrm{NaCl}$ at low $\mathrm{pH}$ in the UF concentrates preserves the functionality of the hairy layer of $\kappa$-casein and decreases the $\mathrm{pH}$ at which acidinduced aggregation begins to occur.

\section{ACKNOWLEDGMENTS}

The work was financially supported by the Danish Dairy Research Foundation and the Danish Governmental Research Program (FØTEK 3). Karsten Bruun Qvist is acknowledged for initiating this work and critically reading the manuscript. The technical assistance from Anni Nielsen is gratefully acknowledged. We would also like to thank Marie Tholstrup Sejersen for performing some of the viscometric measurements and Jes Knudsen at KVL for many fruitful discussions.

\section{REFERENCES}

Barnes, H. A. 1995. A review of the slip (wall depletion) of polymer solutions, emulsions and particle suspensions in viscometers: Its cause, character, and cure. J. Non-Newt. Fluid Mech. 56:221-251.

Barnes, H. A., J. F. Hutton, and K. Walters. 1989. An Introduction to Rheology. Elsevier Science B.V., Amsterdam, The Netherlands.

Bienvenue, A., R. Jiménez-Flores, and H. Singh. 2003a. Rheological properties of concentrated skim milk: Importance of soluble minerals in the changes in viscosity during storage. J. Dairy Sci. 86:3813-3821.

Bienvenue, A., R. Jiménez-Flores, and H. Singh. 2003b. Rheological properties of concentrated skim milk: Influence of heat treatment and genetic variants on the changes in viscosity during storage. J. Agric. Food Chem. 51:6488-6494.

Bird, R. B., R. C. Armstrong, and O. Hassager. 1987. Dynamics of polymeric liquids. Fluid Mechanics. 2nd ed. Vol 1. Wiley Co., New York, NY

Boulet, M., M. Britten, and F. Lamarche. 1998. Voluminosity of some food proteins in aqueous dispersions at various $\mathrm{pH}$ and ionic strengths. Food Hydrocoll. 12:433-441.

Dalgleish, D. G., and A. J. R. Law. 1988. pH-Induced dissociation of bovine casein micelles. I. Analysis of liberated caseins. J. Dairy Res. 55:529-538.

Dalgleish, D. G., P. A. Spagnuolo, and H. D. Goff. 2004. A possible structure of the casein micelle based on high-resolution fieldemission scanning electron microscopy. Int. Dairy J. 14:10251031. 
de Kruif, C. G. 1997. Skim milk acidification. J. Colloid Interface Sci. 185:19-25.

Eilers, H. 1941. Die Viskosität von Emulsionen hochviskoser Stoffe als Funktion der Konzentration. Kolloid. Z. 97:313-321. [In German]

Grufferty, M. B., and P. F. Fox. 1985. Effect of added NaCl on some physiochemical properties of milk. Irish J. Food Sci. Technol. 9:1-9.

Hallström, M., and P. Dejmek. 1988. Rheological properties of ultrafiltrated skim milk. II. Protein voluminosity. Milchwissenschaft 43:95-97.

Hunter, R. J. 1993. Introduction to modern colloid science. Oxford University Press, Oxford, UK.

International Dairy Federation. 1987. Milk: Determination of total phosphorous content (spectrometric method). IDF Standard No. 42A. Int. Dairy Fed., Brussels, Belgium.

International Dairy Federation. 1991a. IDF 15B:1991. Sweetened condensed milk: Determination of the total solids content (reference method). IDF Standard No. 15B. Int. Dairy Fed., Brussels, Belgium.

International Dairy Federation. 1991b. Determination of lactose content: Enzymatic methods. IDF Standard No. 79B. Int. Dairy Fed., Brussels, Belgium.

International Dairy Federation. 1993. Nitrogen content of milk and milk products. International Dairy Federation. IDF Standard No. 20B. Int. Dairy Fed., Brussels, Belgium.

Jordens, K., G. L. Wilkes, J. Janzen, and D. C. Rohlfing. Welch. M.B. 2000. The influence of molecular weight and thermal history on the thermal, rheological, and mechanical properties of metallocene-catalyzed linear polyethylenes. Polymer 41:7175-7192.

Knudsen, J. C., A. O. Karlsson, R. Ipsen, and L. H. Skibstedt. 2005. Rheology of stirred acidified skim milk gels with different particle interactions. Colloids Surf. (accepted)
Le Graët, Y., and F. Gaucheron. 1999. pH-induced solubilization of minerals from casein micelles: Influence of casein concentration and ionic strength. J. Dairy Sci. 66:215-224.

Schkoda, P., A. Hechler, and H. G. Kessler. 1999. Effect of minerals and $\mathrm{pH}$ on rheological properties and syneresis of milk-based acid gels. Int. Dairy J. 9:269-273.

Schrader, K., W. Buchheim, and C. V. Morr. 1997. High pressure effects on the collodial calcium phosphate and the structural integrity of micellar casein in milk. Part 1 . High pressure dissolution of colloidal calcium phosphate in heated milk systems. Nahrung 41:133-138.

Snoeren, T. H. M., A. J. Damman, and H. J. Klok. 1982. The viscosity of skim-milk concentrates. Neth. Milk Dairy J. 36:305-316.

Solanki, G., and S. S. H. Rizvi. 2001. Physico-chemical properties of skim milk retentates from microfiltration. J. Dairy Sci. 84:2381-2391.

Tárrega, A., L. Durán, and E. Costell. 2005. Rheological characterization of semisolid dairy desserts. Effect of temperature. Food Hydrocoll. 19:133-139.

van Boekel, M. A. J. S., and B. Ribadeau-Dumas. 1987. Addendum to the evaluation of the Kjeldahl factor for the conversion of the nitrogen content of milk and milk products to protein content. Neth. Milk Dairy J. 41:281-284.

Vélez-Ruiz, J. F., and G. V. Barbosa-Cánovas. 1998. Rheological properties of concentrated milk as a function of concentration, temperature and storage time. J. Food Eng. 35:177-190.

Walstra, P. 1979. The voluminosity of bovine casein micelles and some of its implications. J. Dairy Res. 46:317-323.

Walstra, P. 1999. Casein sub-micelles: Do they exist? Int. Dairy J. 9:189-192.

Walstra, P., and R. Jenness. 1984. Dairy chemistry and physics. John Wiley \& Sons, Inc., New York, NY. 